\section{Hydrogen Cyanamide Accelerates Vegetative Budbreak and Shortens Fruit Development Period of Blueberry}

\author{
Jeffrey G. Williamson \\ Horticultural Sciences Department, IFAS, University of Florida, Gainesville, \\ FL 32611-0690
}

Gerard Krewer

Horticulture Department, University of Georgia, Tifton, GA 31793-1209

\author{
Brian E. Maust ${ }^{1}$ and E. Paul Miller \\ Horticultural Sciences Department, IFAS, University of Florida, Gainesville, \\ FL 32611-0690
}

Additional index words. Dormex, flower bud thinning, Vaccinium ashei, V. corymbosum

\begin{abstract}
Experiments were conducted in north Florida and south Georgia to determine the effects of $\mathrm{H}_{2} \mathrm{CN}_{2}$ sprays on vegetative and reproductive growth of blueberry. In Florida, mature, field-grown 'Misty' southern highbush (Vaccinium corymbosum L. hybrid) blueberry plants were sprayed to drip with $0,10.2$, or $20.4 \mathrm{~g} \cdot \mathrm{L}^{-1}$ of $\mathrm{H}_{2} \mathrm{CN}_{2}$ [hereafter referred to as $0 \%, 1.0 \%$, and $\left.2.0 \%(\mathrm{v} / \mathrm{v}) \mathrm{H}_{2} \mathrm{CN}_{2}\right]$ on 20 Dec. 1996 and $7 \mathrm{Jan} .1997$. During the following winter, mature 'Misty' southern highbush and 'Climax' rabbiteye (V. ashei Reade) plants were sprayed to drip with $0,7.6$, or $15.3 \mathrm{~g} \cdot \mathrm{L}^{-1}$ of $\mathrm{H}_{2} \mathrm{CN}_{2}$ [hereafter referred to as $0 \%, 0.75 \%$, and $1.5 \%(\mathrm{v} / \mathrm{v}) \mathrm{H}_{2} \mathrm{CN}_{2}$ ] on 17 Dec. 1997 and 6 Jan. 1998. For all experiments, plants were dormant and leafless, with slightly swollen flower buds, at the time of spray applications. Generally, $\mathrm{H}_{2} \mathrm{CN}_{2}$ sprays increased the extent and earliness of vegetative budbreak and canopy establishment and advanced flowering slightly. The number of vegetative budbreaks usually increased linearly with increasing spray concentrations. In Florida, $\mathrm{H}_{2} \mathrm{CN}_{2}[0.75 \%$ to $1.0 \%(\mathrm{v} / \mathrm{v})]$ sprays increased mean fruit fresh weight and yield, and shortened the fruit development period (FDP) compared to controls. However, $\mathrm{H}_{2} \mathrm{CN}_{2}$ sprays ranging in concentration from $1.5 \%$ to $2.0 \%$ (v/v) resulted in significant flower bud injury and reduced total fruit yield compared to controls. In south Georgia, 27 of 37 field trials conducted between 1991 and 1998 on several rabbiteye and southern highbush cultivars indicated that leaf development was significantly enhanced by $\mathrm{H}_{2} \mathrm{CN}_{2} . \mathrm{H}_{2} \mathrm{CN}_{2}$ shows potential for increasing early fruit maturity, fruit size, and yield of southern highbush and rabbiteye blueberry cultivars with poor leaf development characteristics in low-chill production regions. Chemical name used: hydrogen cyanamide $\left(\mathrm{H}_{2} \mathrm{CN}_{2}\right)$.
\end{abstract}

Commercial blueberry production in south Georgia and Florida has expanded rapidly since 1990 with over 2300 ha now planted in low and moderate winter chilling zones. In Florida, southern highbush blueberry comprise the majority of commercial blueberry acreage and in south Georgia rabbiteye blueberry are the predominant commercial species. Chilling requirements for cultivars grown in this region of the United States vary from 200 to 600 chill units. The most profitable marketing window for this fruit is from about 1 Apr. to 20 May. In recent years below average chilling has resulted in poor spring flowering and foliation which has reduced the amount of fruit ripening during this market window (Lyrene and Williamson, 1997; NeSmith and Bridges, 1992).

Fruit growth and development of blueberry are strongly influenced by fruit load, leaf

Received for publication 17 Nov. 2000. Accepted for publication 5 Sept. 2001. Florida Agricultural Experiment Station Journal Series no. R-08210.

${ }^{1}$ Current address: Centro de Investigacion Cientifica de Yucatan, A.P. 87, Cordemex, Merida, Yucatan, Mexico.

HortSCience, Vol. 37(3), June 2002 poor-leafing cultivars, particularly under conditions of marginal chilling. $\mathrm{H}_{2} \mathrm{CN}_{2}$ (Dormex; SKW Trosberg AG, Trosberg, Germany) is in widespread use around the world to enhance leaf and flower budbreak of numerous deciduous fruit crops (Dokoozlian and Williams, 1995; Erez, 1987; Krewer et al., 1997; Shulman et al., 1986; Sieler et al., 1991). This is the first detailed report of use of $\mathrm{H}_{2} \mathrm{CN}_{2}$ on blueberry under field conditions.

The objectives of this research were to determine the effects of $\mathrm{H}_{2} \mathrm{CN}_{2}$ rate and time of application on vegetative and reproductive growth of various cultivars of field-grown rabbiteye and southern highbush blueberries.

\section{Materials and Methods}

1997 Florida experiment. Mature, fieldgrown, 'Misty' southern highbush blueberry plants were sprayed to run-off with $0,10.2$, or $20.4 \mathrm{~g} \cdot \mathrm{L}^{-1}$ concentrations of $\mathrm{H}_{2} \mathrm{CN}_{2}$ [hereafter referred to as $0 \%, 1 \%$, and $2 \%$ (v/v) $\mathrm{H}_{2} \mathrm{CN}_{2}$ sprays] at a commercial north Florida blueberry planting on 20 Dec. 1996 or 7 Jan. 1997. A nonionic surfactant was included at $0.25 \%$ $(\mathrm{v} / \mathrm{v})$ in each treatment. Accumulated chilling hours (hours between 0 and $7.2^{\circ} \mathrm{C}$ ) were 36 and 40 on 20 Dec. and 7 Jan., respectively. Total accumulated chilling was $134 \mathrm{~h}$ by 20 Feb. Plants were dormant and leafless with slightly swollen buds [Stage 2 (Spiers, 1978)] at the time of spray applications. Two-plant plots were used with a minimum of one buffer plant between plots. A randomized complete-block design with seven replications per treatment was used. Three representative canes per plant (total of 42 canes per treatment) were randomly selected before treatments were applied and used for detailed measurements of flower and fruit development, and vegetative growth. After all fruit were harvested (late May), these canes were harvested to determine leaf areas per unit of cane length. Analysis of variance (ANOVA) and regression were used to determine treatment effects.

1998 Florida experiment. Mature, fieldgrown, 'Misty' southern highbush and 'Climax' rabbiteye blueberry plants were sprayed to runoff with $0,7.7$, and $15.4 \mathrm{~g} \cdot \mathrm{L}^{-1}$ concentrations of hydrogen cyanamide [hereafter referred to as $0 \%, 0.75 \%$ and $1.5 \%(\mathrm{v} / \mathrm{v}) \mathrm{H}_{2} \mathrm{CN}_{2}$ sprays] on 17 Dec. 1997 and 6 Jan. 1998 at a commercial north Florida blueberry planting. A nonionic surfactant at $0.25 \% \mathrm{v} / \mathrm{v}$ was included in each spray. Accumulated chilling hours (hours between 0 and $7.2^{\circ} \mathrm{C}$ ) were 130 and 243 on 17 Dec. and 6 Jan., respectively. Total accumulated chilling was $502 \mathrm{~h}$ on $20 \mathrm{Feb}$. Plants were dormant with slightly swollen flower buds [stage 2, (Spiers, 1978)] at the time of spray applications. A randomized complete-block design with seven replications per treatment was used. Single-plant plots with at least one buffer plant between plots were used. Four canes per plot (total of 28 canes per treatment) were selected before the treatments were applied for detailed measurements of flower, fruit, and vegetative bud development. All ripe fruit were harvested at 3-4 d intervals from entire plants and from selected representative canes beginning at first 
fruit ripening. Fruit from the selected canes were harvested separately. The ANOVA and regression were used to determine treatment effects.

1991-98 south Georgia experiments. During the course of 8 years, 36 experiments were conducted in growers fields to determine the commercial practicality of using $\mathrm{H}_{2} \mathrm{CN}_{2}$ as a leaf enhancing agent for southern highbush and rabbiteye blueberries. Several different experimental designs were used with the most common being a randomized complete block with three replications of 10 bushes per replication per treatment. Most applications were made with an airblast sprayer applying $\approx 365$ L/ha of finished spray. $\mathrm{H}_{2} \mathrm{CN}_{2}$ was applied at rates between $0.5 \%$ and $2 \%(\mathrm{v} / \mathrm{v})$. Surfactant was used at the rate of $0.25 \%(\mathrm{v} / \mathrm{v})$ in most experiments. To obtain vegetative budbreak data, usually two shoots per bush were measured and vegetative budbreaks counted to obtain vegetative budbreaks per $\mathrm{cm}$ of shoot length. In trials where vegetative budbreak percentages were obtained, the total number of active and inactive vegetative buds per shoot was counted. In cases were vegetative budbreak development was rated, typically each bush was assessed using the scale developed by NeSmith et al. (1998).

\section{Results and Discussion}

1997 Florida experiment. $\mathrm{All}_{2} \mathrm{CN}_{2}$ sprays increased the extent and earliness of vegetative budbreak and canopy establishment of 'Misty' southern highbush blueberry. However, no interactions between spray concentration and date were observed; nor were differences observed between the two spray dates (data not reported). Therefore, only the main effects of spray concentration are discussed. The number of vegetative budbreaks per shoot length increased linearly with increased $\mathrm{H}_{2} \mathrm{CN}_{2}$ spray concentration at both measuring dates (Table 1). Both $\mathrm{H}_{2} \mathrm{CN}_{2}$ spray concentrations resulted in earlier fruit ripening compared to the controls. For example, by 15 Apr., $41 \%$ and $61 \%$ of all fruit on representative canes were ripe for the $1 \%$ and $2 \% \mathrm{H}_{2} \mathrm{CN}_{2}$ treatments, respectively, compared with only $7 \%$ for the controls. By the end of April, a large majority of fruit from the $\mathrm{H}_{2} \mathrm{CN}_{2}$ treatments ( $89 \%$ to $97 \%$ ) had ripened compared to $\approx 60 \%$ of the fruit from representative canes on control plants. In general, $\mathrm{H}_{2} \mathrm{CN}_{2}$ advanced harvest by $10-14 \mathrm{~d}$. Since bloom date was not affected by $\mathrm{H}_{2} \mathrm{CN}_{2}$ treatments (data not shown), we conclude that FDP was shortened by $\mathrm{H}_{2} \mathrm{CN}_{2}$ treatments.

$\mathrm{H}_{2} \mathrm{CN}_{2}$ sprays also resulted in greater fruit fresh weights (Table 1). Mean fruit FW increased linearly as $\mathrm{H}_{2} \mathrm{CN}_{2}$ spray concentrations increased. The reduction in FDP and increase in mean fruit $\mathrm{FW}$ of the $1 \% \mathrm{H}_{2} \mathrm{CN}_{2}$ treatment over the control were probably due to greater and earlier spring leafing caused by $\mathrm{H}_{2} \mathrm{CN}_{2}$. Maust et al. (1999) showed that shorter FDP and increased fruit FW were correlated with greater leaf : fruit ratios during fruit development of southern highbush blueberry. Table 1 shows greater leaf area per shoot

Table 1. Effect of $\mathrm{H}_{2} \mathrm{CN}_{2}$ spray concentration on the number of vegetative budbreaks/cm of shoot length and cumulative percent of total fruit harvested of representative canes of field-grown 'Misty' blueberry (1997).

\begin{tabular}{|c|c|c|c|c|c|c|c|c|}
\hline \multirow{2}{*}{$\begin{array}{l}\text { Spray } \\
\text { concn } \\
\left(\% \text { of } \mathrm{H}_{2} \mathrm{CN}_{2}\right)\end{array}$} & \multicolumn{2}{|c|}{$\begin{array}{c}\text { No. of } \\
\text { vegetative budbreaks/ } \\
\text { cm shoot length }\end{array}$} & \multirow{2}{*}{$\begin{array}{l}\text { Leaf area } \\
\left(\mathrm{cm}^{2}\right) \text { per } \mathrm{cm} \\
\text { shoot length }\end{array}$} & \multicolumn{4}{|c|}{$\begin{array}{l}\text { Cumulative percent of total berries } \\
\text { on canes at harvest dates }(\mathrm{g})\end{array}$} & \multirow{2}{*}{$\begin{array}{l}\text { Mean } \\
\text { berry } \\
\text { fresh wt } \\
(\mathrm{g}) \\
\end{array}$} \\
\hline & 31 Jan. & 14 Feb. & & 7 Apr. & 15 Apr. & 22 Apr. & $29 \mathrm{Apr}$. & \\
\hline$\overline{0}$ & 0 & 0.01 & 4.9 & 0 & 6.9 & 27.5 & 61.7 & 1.44 \\
\hline 1 & 0.09 & 0.11 & 8.9 & 6.4 & 41.0 & 68.0 & 89.2 & 1.64 \\
\hline 2 & 0.23 & 0.24 & 8.7 & 10.7 & 61.4 & 89.1 & 97.1 & 1.86 \\
\hline \multicolumn{9}{|c|}{ Significance } \\
\hline $\mathrm{L}$ & $* * *$ & $* * *$ & NS & $* * *$ & $* * *$ & NS & NS & $* * *$ \\
\hline Q & NS & NS & $*$ & NS & NS & $* * *$ & $* * *$ & NS \\
\hline
\end{tabular}

length for the $\mathrm{H}_{2} \mathrm{CN}_{2}$ treatments compared with the controls. This is indicative of greater canopy establishment and suggests that leaf : fruit ratios were greater for the $\mathrm{H}_{2} \mathrm{CN}_{2}$ plants than for the control plants. Although data for flower bud mortality was not collected, no significant flower bud mortality was noted for the $1 \% \mathrm{H}_{2} \mathrm{CN}_{2}$ spray. However, considerable flower mortality was observed at the $2 \% \mathrm{H}_{2} \mathrm{CN}_{2}$ concentration. Flower bud thinning in the $2 \%$ $\mathrm{H}_{2} \mathrm{CN}_{2}$ treatment probably further increased leaf : fruit ratios and may explain the additional increase in early fruit ripening and greater mean fruit fresh weight gained from that treatment. This explanation of larger, earlierripening fruit from the higher $\mathrm{H}_{2} \mathrm{CN}_{2}$ spray concentration is supported by the fact that leaf areas per $\mathrm{cm}$ shoot length were similar for the two $\mathrm{H}_{2} \mathrm{CN}_{2}$ treatments (Table 1).

1998 Florida experiment. Based on 1997 results, $\mathrm{H}_{2} \mathrm{CN}_{2}$ concentrations for 1998 were decreased. All $\mathrm{H}_{2} \mathrm{CN}_{2}$ treatments increased the extent and earliness of vegetative budbreak for 'Misty' southern highbush and 'Climax' rabbiteye blueberry compared to controls (Table 2). As in 1997, both spray timings were similar in their effects on vegetative budbreak and fruit development. Therefore only the main effects of spray concentration are discussed. Vegetative budbreak for both cultivars increased as $\mathrm{H}_{2} \mathrm{CN}_{2}$ spray concentration increased. For 'Misty', the percentage of vegetative buds which grew on representative canes of control plants remained very low throughout fruit development (Table 2). However, $\mathrm{H}_{2} \mathrm{CN}_{2}$ treatments resulted in a large and rapid increase in vegetative budbreak. A similar response to $\mathrm{H}_{2} \mathrm{CN}_{2}$ occurred for 'Climax'. By 27 Feb., the number of growing vegetative buds was 4- to 8-fold greater for the $\mathrm{H}_{2} \mathrm{CN}_{2}$ treatments than for the controls (Table 2). Late during 'Climax' fruit development (7 Apr.), vegetative budbreak was still $\approx 50 \%$ greater for the $\mathrm{H}_{2} \mathrm{CN}_{2}$ treatments than for controls.

Fruit ripening of 'Misty' and 'Climax' was advanced by $\mathrm{H}_{2} \mathrm{CN}_{2}$ sprays (Tables 3 and 4). Significantly more 'Misty' fruit was harvested from the $\mathrm{H}_{2} \mathrm{CN}_{2}$ treatments than from the controls during the 16-30 Apr. period and less fruit was harvested from $\mathrm{H}_{2} \mathrm{CN}_{2}$ treated plants during the final harvest period (16-31 May) (Table 3). The economic impact of this is very significant since fruit ripening in late April averaged \$21.53/kg (1997-99), while fruit ripening in late May averaged $\$ 11.47 / \mathrm{kg}$ (VanSickle, 2000). The effects of $\mathrm{H}_{2} \mathrm{CN}_{2}$ on earliness of 'Climax' fruit harvest were similar to those of 'Misty' but less pronounced. During the first half of the 'Climax' harvest season, fruit harvest was greater for the $0.75 \%$ $\mathrm{H}_{2} \mathrm{CN}_{2}$ treatment than for the control plants (Table 4). Total berry yield was increased slightly by the $0.75 \%$ rate of $\mathrm{H}_{2} \mathrm{CN}_{2}$ and decreased by the $1.5 \%$ rate for both cultivars (Tables 3 and 4).

Mean berry FW of 'Misty' was increased by both $\mathrm{H}_{2} \mathrm{CN}_{2}$ spray concentrations compared to the controls (Table 3). Although FW of the $1.5 \% \mathrm{H}_{2} \mathrm{CN}_{2}$-treated fruit tended to be greater than the $0.75 \% \mathrm{H}_{2} \mathrm{CN}_{2}$ fruit during some harvest periods, these differences were small and inconsistent. However, a difference in individual fruit $\mathrm{FW}$ of $\approx 0.3 \mathrm{~g}$, as observed between the $0.75 \% \mathrm{H}_{2} \mathrm{CN}_{2}$ treatment and the control, is noteworthy and of practical and economic significance.

Greater total fruit yield from the $0.75 \%$ $\mathrm{H}_{2} \mathrm{CN}_{2}$ vs. the control is probably in part due to the increase in average fruit $\mathrm{FW}$ resulting from the $\mathrm{H}_{2} \mathrm{CN}_{2}$ treatment. As in the 1997 experiment, the higher concentration of $\mathrm{H}_{2} \mathrm{CN}_{2}$ resulted in some flower bud mortality which probably accounts for the reduction in total yield for that treatment.

Table 2. Effect of $\mathrm{H}_{2} \mathrm{CN}_{2}$ spray concentration on vegetative budbreak for representative canes of 'Misty' and 'Climax' blueberry following treatment (1998).

\begin{tabular}{|c|c|c|c|c|c|c|}
\hline \multirow{2}{*}{$\begin{array}{l}\text { Spray } \\
\text { concentration } \\
\left(\% \mathrm{H}_{2} \mathrm{CN}_{2}\right)\end{array}$} & \multicolumn{3}{|c|}{$\begin{array}{c}\text { Vegetative buds } \\
\text { growing ( } \% \text { of total) }\end{array}$} & \multicolumn{3}{|c|}{$\begin{array}{c}\text { Vegetative buds } \\
\text { growing/cm shoot length }\end{array}$} \\
\hline & 22 Jan. & 6 Feb. & 6 Mar. & $10 \mathrm{Feb}$. & 27 Feb. & 7 Apr. \\
\hline & \multicolumn{3}{|c|}{ Misty } & \multicolumn{3}{|c|}{ Climax } \\
\hline 0 & 0 & 0 & 2 & 0 & 0.03 & 0.21 \\
\hline 0.75 & 33 & 40 & 54 & 0.11 & 0.13 & 0.31 \\
\hline 1.5 & 71 & 74 & 71 & 0.24 & 0.24 & 0.30 \\
\hline \multicolumn{7}{|c|}{ Significance } \\
\hline $\mathrm{L}$ & $* * *$ & $* * *$ & $* * *$ & $* * *$ & $* * *$ & NS \\
\hline Q & NS & NS & NS & NS & NS & $*$ \\
\hline
\end{tabular}


Table 3. Effect of $\mathrm{H}_{2} \mathrm{CN}_{2}$ spray concentration on time of harvest, fruit yield and mean fruit fresh weight of field-grown 'Misty' southern highbush blueberry (1998).

\begin{tabular}{|c|c|c|c|c|c|c|c|c|c|}
\hline \multirow{3}{*}{$\begin{array}{l}\text { Spray } \\
\text { concentration } \\
\left(\% \mathrm{H}_{2} \mathrm{CN}_{2}\right)\end{array}$} & \multicolumn{8}{|c|}{ Harvest period } & \multirow[b]{3}{*}{$\begin{array}{c}\text { Total } \\
\text { yield }(\mathrm{g})\end{array}$} \\
\hline & \multicolumn{2}{|c|}{ 1-15 Apr. } & \multicolumn{2}{|c|}{ 16-30 Apr. } & \multicolumn{2}{|c|}{ 1-15 May } & \multicolumn{2}{|c|}{16 May-1 June } & \\
\hline & $\begin{array}{l}\text { Yield } \\
(\mathrm{g})\end{array}$ & $\begin{array}{c}\text { Mean berry } \\
\text { wt }(\mathrm{g})\end{array}$ & $\begin{array}{l}\text { Yield } \\
(\mathrm{g})\end{array}$ & $\begin{array}{c}\text { Mean berry } \\
\text { wt }(\mathrm{g})\end{array}$ & $\begin{array}{c}\text { Yield } \\
(\mathrm{g})\end{array}$ & $\begin{array}{c}\text { Mean berry } \\
\text { wt }(\mathrm{g})\end{array}$ & $\begin{array}{c}\text { Yield } \\
(\mathrm{g})\end{array}$ & $\begin{array}{c}\text { Mean berry } \\
\text { wt }(\mathrm{g})\end{array}$ & \\
\hline 0 & 248 & 1.53 & 1310 & 1.63 & 1733 & 1.49 & 1790 & 1.14 & 5050 \\
\hline 0.75 & 360 & 1.88 & 2710 & 1.94 & 1842 & 1.57 & 811 & 1.36 & 5860 \\
\hline 1.5 & 361 & 1.92 & 2050 & 1.97 & 748 & 1.45 & 215 & 1.41 & 3370 \\
\hline \multicolumn{10}{|c|}{ Significance } \\
\hline $\mathrm{L}$ & NS & $* * *$ & $*$ & NS & NS & NS & $* * *$ & $* * *$ & NS \\
\hline Q & NS & NS & $* *$ & $* *$ & $* * *$ & $*$ & NS & NS & $*$ \\
\hline
\end{tabular}

South Georgia experiments. The south Georgia field trials between 1991 and 1998 included $\mathrm{H}_{2} \mathrm{CN}_{2}$ spray concentrations ranging from $0.5 \%$ to $2.0 \%$ (v/v). Generally, $\mathrm{H}_{2} \mathrm{CN}_{2}$ increased and advanced vegetative budbreak for a variety of rabbiteye and southern highbush blueberry cultivars during most years and at most spray concentrations (Table 5). Vegetative budbreak, or vegetative stage rating, was significantly increased in 27 out of 37 field trials. To avoid unnecessary duplication, information from a representative group of 22 of the 37 trials is included in Table 5. Although poor winter chilling increases the need for $\mathrm{H}_{2} \mathrm{CN}_{2}$, even in years of average or above average winter chilling, excellent responses were observed on rabbiteye and southern highbush cultivars with poor leaf development characteristics (Table 5, 1996 and 1997). Variable results among cultivars were most often observed in trials using $0.5 \% \mathrm{H}_{2} \mathrm{CN}_{2}$. Flower bud mortality was most commonly observed in trials where some flower buds were at stage 3 or greater, especially if $\mathrm{H}_{2} \mathrm{CN}_{2}$ was applied at $1 \%$ or greater. This agrees with previous work by Williamson, et al. (2001). Flower bud mortality was observed, but not quantified, in 7 of the 37 trials. It was normally limited to the most advanced terminal bud which had reached stage 3 at the time of application. This damage to flower buds may have been partly responsible for the accelerated leaf development noted in five of these seven trials. Cultivars responding well to $\mathrm{H}_{2} \mathrm{CN}_{2}$ were 'Climax' rabbiteye blueberry and nearly all southern highbush blueberry cultivars. Fruit ripening was usually accelerated by $\mathrm{H}_{2} \mathrm{CN}_{2}$. Although yield was not measured, observations indicated that the first harvest date was advanced by several days and a greater percentage of fruit was harvested during the first and second harvest dates for $\mathrm{H}_{2} \mathrm{CN}_{2}$ treatments than for

Table 4. Effect of $\mathrm{H}_{2} \mathrm{CN}_{2}$ spray concentration on time of fruit harvest and fruit yield ( $\mathrm{g}$ ) of field-grown 'Climax' blueberry (1998).

\begin{tabular}{|c|c|c|c|}
\hline \multirow{2}{*}{$\begin{array}{l}\text { Spray } \\
\text { concn } \\
\left(\% \mathrm{H}_{2} \mathrm{CN}_{2}\right)\end{array}$} & \multicolumn{2}{|c|}{$\begin{array}{c}\text { Fruit wt }(\mathrm{g}) \\
\text { from harvest period }\end{array}$} & \multirow{2}{*}{$\begin{array}{c}\text { Total } \\
\text { yield } \\
(\mathrm{g})\end{array}$} \\
\hline & 1 May-1 June & 2 June-30 June & \\
\hline$\overline{0}$ & 1982 & 1379 & 3361 \\
\hline 0.75 & 2472 & 1619 & 4091 \\
\hline 1.5 & 1597 & 413 & 2010 \\
\hline \multicolumn{4}{|c|}{ Significance } \\
\hline L & $\begin{array}{l}\text { NS } \\
* *\end{array}$ & $\begin{array}{l}\text { NS } \\
* * *\end{array}$ & $\begin{array}{l}\text { NS } \\
* * *\end{array}$ \\
\hline Q & $* *$ & $* * *$ & $* * *$ \\
\hline
\end{tabular}

HortSCIENCE, Vol. 37(3), June 2002 controls. This effect has economic implications since prices can drop rapidly in the spring (VanSickle, 2000). Another potentially beneficial effect on some cultivars is improved bush architecture in the following year. Since the number of lateral vegetative buds breaking often is increased, cultivars with poor lateral

shoot development could have improved cropping potential the following year. The carryover effects of $\mathrm{H}_{2} \mathrm{CN}_{2}$ on potential yield the season(s) following application need further investigation.

Cultivars which responded most erratically to $\mathrm{H}_{2} \mathrm{CN}_{2}$ were 'Brightwell' and 'Tifblue'.

Table 5. Effect of season and cultivar on budbreak reaction of blueberry to $\mathrm{H}_{2} \mathrm{CN}_{2}$ sprays in south Georgia.

\begin{tabular}{|c|c|c|c|c|c|c|c|c|}
\hline Year & $\begin{array}{c}\text { Winter } \\
\text { chilling } \\
\text { (h) }\end{array}$ & Cultivar & $\begin{array}{c}\text { Date } \\
\text { of } \\
\text { treatment }\end{array}$ & $\begin{array}{c}\mathrm{H}_{2} \mathrm{CN}_{2} \\
(\%)\end{array}$ & $\begin{array}{l}\text { Veg. bud- } \\
\text { breaks/cm } \\
\text { shoot (date) }\end{array}$ & $\begin{array}{l}\text { Veg. bud- } \\
\text { break }(\%) \\
\text { (date) }\end{array}$ & $\begin{array}{l}\text { Veg. bud } \\
\text { stage }^{\mathrm{z}} \\
\text { (date) }\end{array}$ & $\begin{array}{c}\text { Flower } \\
\text { bud } \\
\text { stage }^{y}\end{array}$ \\
\hline \multirow[t]{3}{*}{1991} & 607 & Tifblue & $1 / 23$ & 0 & $0.21 \mathrm{~b}^{\mathrm{x}}(4 / 1)$ & --- & --- & $\overline{---}$ \\
\hline & & & $1 / 23$ & 1 & $0.33 \mathrm{~b}$ & --- & --- & --- \\
\hline & & & $2 / 1$ & 2 & $0.62 \mathrm{a}$ & --- & --- & --- \\
\hline \multirow[t]{2}{*}{1992} & 708 & Tifblue & $2 / 18$ & 0 & 0.34 a (4/15) & --- & --- & --- \\
\hline & & & & 0.5 & $0.40 \mathrm{a}$ & --- & --- & --- \\
\hline \multirow[t]{6}{*}{1995} & 525 & Climax & $1 / 31$ & 0 & $0.36 \mathrm{~b}(4 / 15)$ & --- & --- & --- \\
\hline & & & & 0.5 & $0.48 \mathrm{a}$ & --- & --- & --- \\
\hline & & Premier & $1 / 31$ & 0 & $0.31 \mathrm{a}(4 / 15)$ & --- & --- & --- \\
\hline & & & & 0.5 & $0.27 \mathrm{a}$ & --- & --- & --- \\
\hline & & Tifblue & $2 / 13$ & 0 & $0.33 \mathrm{a}(4 / 15)$ & --- & --- & --- \\
\hline & & & & 0.5 & $0.35 \mathrm{a}$ & --- & --- & --- \\
\hline \multirow[t]{17}{*}{1996} & 1009 & Bluecrisp & $1 / 5$ & 0 & --- & $19 \mathrm{~b}(2 / 24)$ & $3.4 \mathrm{~b}$ & --- \\
\hline & & & & 1 & --- & $70 \mathrm{a}$ & $4.9 \mathrm{a}$ & --- \\
\hline & & & & 1.25 & --- & $65 \mathrm{a}$ & $4.5 \mathrm{a}$ & --- \\
\hline & & Brightwell & $1 / 30$ & 0 & --- & $67 \mathrm{a}(3 / 23)$ & $5.5 \mathrm{~b}$ & --- \\
\hline & & & & 0.5 & --- & $69 \mathrm{a}$ & $6.0 \mathrm{a}$ & --- \\
\hline & & Brightwell & $1 / 6$ & 0 & --- & $0 \mathrm{~b}(2 / 24)$ & $0.8 \mathrm{~b}$ & --- \\
\hline & & & & 1 & --- & $63 \mathrm{a}$ & $4.4 \mathrm{a}$ & --- \\
\hline & & Brightwell & $1 / 5$ & 0 & --- & 67 a (3/28) & $5.5 \mathrm{a}$ & --- \\
\hline & & & & 1 & --- & $69 \mathrm{a}$ & $6.0 \mathrm{a}$ & --- \\
\hline & & Climax & $1 / 30$ & 0 & --- & $47 \mathrm{~b}(3 / 23)$ & $4.3 \mathrm{~b}$ & --- \\
\hline & & & & 0.5 & --- & $60 \mathrm{a}$ & $5.1 \mathrm{a}$ & --- \\
\hline & & Climax & $1 / 5$ & 0 & --- & $49 \mathrm{~b}(3 / 23)$ & $4.4 \mathrm{~b}$ & --- \\
\hline & & & & 1 & --- & $71 \mathrm{a}$ & $5.7 \mathrm{a}$ & --- \\
\hline & & FL 81-156 & $1 / 6$ & 0 & --- & $20 \mathrm{~b}(3 / 3)$ & $3.2 \mathrm{~b}$ & --- \\
\hline & & & & 1 & --- & $74 \mathrm{a}$ & $5.7 \mathrm{a}$ & --- \\
\hline & & Southern Belle & $1 / 6$ & 0 & --- & $19 \mathrm{~b}(2 / 24)$ & $3.0 \mathrm{~b}$ & --- \\
\hline & & & & 1 & --- & $72 \mathrm{a}$ & $4.9 \mathrm{a}$ & --- \\
\hline \multirow[t]{10}{*}{1997} & 779 & Bladen & $1 / 19$ & 0 & --- & --- & 1.3 b (3/6) & --- \\
\hline & & & & 1 & --- & --- & $2.8 \mathrm{a}$ & --- \\
\hline & & Climax & $2 / 10$ & 0 & --- & --- & $1.6 \mathrm{~b}(3 / 13)$ & --- \\
\hline & & & & 0.75 & --- & --- & $2.4 \mathrm{a}$ & --- \\
\hline & & Climax & $1 / 19$ & 0 & --- & --- & $2.8 \mathrm{~b}(3 / 6)$ & --- \\
\hline & & & & 1 & --- & --- & $4.7 \mathrm{a}$ & --- \\
\hline & & Southern Belle & $1 / 19$ & 0 & --- & --- & $5.2 \mathrm{~b}(3 / 9)$ & --- \\
\hline & & & & 1 & --- & --- & $5.7 \mathrm{a}$ & --- \\
\hline & & Brightwell & $1 / 27$ & 0 & --- & --- & $2.8 \mathrm{~b}(3 / 11)$ & --- \\
\hline & & & & 0.75 & --- & --- & $5.6 \mathrm{a}$ & --- \\
\hline \multirow{8}{*}{1998} & 683 & O'Neal & $1 / 14$ & 0 & --- & $9.8 \mathrm{~b}$ & $1.0 \mathrm{~b}(2 / 19)$ & $4.1 \mathrm{~b}$ \\
\hline & & & & 0.75 & --- & $185 \mathrm{a}$ & $1.5 \mathrm{a}$ & $5.4 \mathrm{a}$ \\
\hline & & Bladen & $1 / 14$ & 0 & --- & $20.6 \mathrm{~b}$ & $1.1 \mathrm{~b}(2 / 19)$ & $2.7 b$ \\
\hline & & & & 0.75 & --- & $44.6 \mathrm{a}$ & $2.8 \mathrm{a}$ & $3.9 \mathrm{a}$ \\
\hline & & Climax & $1 / 15$ & 0 & --- & $21.6 \mathrm{~b}$ & $1.3 \mathrm{~b}(2 / 14)$ & $2.9 \mathrm{~b}$ \\
\hline & & & & 0.75 & --- & $36.7 \mathrm{a}$ & $2.1 \mathrm{a}$ & $3.8 \mathrm{a}$ \\
\hline & & Tifblue & $1 / 15$ & 0 & --- & $18.3 \mathrm{~b}$ & $1.3 \mathrm{~b}(2 / 14)$ & $2.3 \mathrm{a}$ \\
\hline & & & & 0.75 & --- & $38.1 \mathrm{a}$ & $2.0 \mathrm{a}$ & $2.6 \mathrm{a}$ \\
\hline
\end{tabular}

${ }^{2}$ Numerical scale for vegetative bud development from NeSmith et al. (1999)

${ }^{y}$ Numerical scale for flower bud development from Spiers (1978).

${ }^{\mathrm{x}}$ Means separation within columns, years, and cultivars, $P \leq 0.05$. 
These cultivars are late season rabbiteyes with good natural leaf bud development ability. Although leaf budbreak early in the spring can be accelerated by $\mathrm{H}_{2} \mathrm{CN}_{2}$ on cultivars such as 'Brightwell', later in the spring these differences can fade (Table 5, 1996). In the Georgia trials, flower bud development in the spring was typically advanced 1-2 d by $\mathrm{H}_{2} \mathrm{CN}_{2}$. However, in $1998, \mathrm{H}_{2} \mathrm{CN}_{2}$ advanced flower bud development by 0.9 bud stages or $\approx 1$ week on 'Climax' (Table 5, 1998). Most growers producing southern highbush blueberries have overhead irrigation for freeze protection so slightly advanced flowering is normally of limited concern. Variable results among cultivars were observed for $0.5 \%$ $\mathrm{H}_{2} \mathrm{CN}_{2}$ applied during a low chill year (1995). In this case, vegetative budbreak was increased for 'Climax' but not for 'Tifblue' or 'Premier'. In 1998, with 683 h of accumulated pretreatment chilling, all cultivars tested responded to $0.75 \% \mathrm{H}_{2} \mathrm{CN}_{2}$ with increased and advanced vegetative budbreak, and with advanced floral budbreak for all cultivars except 'Tifblue'.

Collectively, these experiments clearly illustrate the efficacy of $\mathrm{H}_{2} \mathrm{CN}_{2}$ in promoting earlier and stronger leafing of some southern highbush and rabbiteye blueberry cultivars which, in turn, results in earlier ripening berries, increased berry fresh weight and, in some cases, a slight increase in total yield. Increased vegetative budbreak and earlier ripening have been shown for both rabbiteye and southern highbush blueberries under a range of environmental and climatic conditions during several years. The increase in vegetative budbreak was rate sensitive and increased as $\mathrm{H}_{2} \mathrm{CN}_{2}$ spray concentration increased up to $2 \%(\mathrm{v} / \mathrm{v})$, the highest concentration tested. However, $\mathrm{H}_{2} \mathrm{CN}_{2}$ spray concentrations of $1.5 \%$ to $2 \%$ (v/ $\mathrm{v}$ ) resulted in significant flower bud injury and reduced yields. A range of $\mathrm{H}_{2} \mathrm{CN}_{2}$ spray concentrations which has consistently shown increased leafing and earlier fruit ripening without significant flower bud damage is $0.75 \%$ to $1.0 \%(\mathrm{v} / \mathrm{v})$.

Field applications of $\mathrm{H}_{2} \mathrm{CN}_{2}$ during midDecember to early January (Florida) and early to late January (Georgia) consistently increased vegetative budbreak and shortened FDPs. Within these time frames, differences from spray application dates were nonsignificant. However, year to year differences in $\mathrm{H}_{2} \mathrm{CN}_{2}$ efficacy suggest that the accumulation of significant chilling hours prior to treatment with $\mathrm{H}_{2} \mathrm{CN}_{2}$ is beneficial for its intended effects. Williamson et al. (2001) reported that application of $\mathrm{H}_{2} \mathrm{CN}_{2}$ to plants that had received no chilling, or to plants with more than $30 \%$ stage 3 flower buds (Spiers, 1978), resulted in higher flower bud mortality and, in some cases, less vegetative budbreak than when $\mathrm{H}_{2} \mathrm{CN}_{2}$ was applied to plants with significant pretreatment chilling, but before flower bud swell progressed past stage 2 . The potential benefits of $\mathrm{H}_{2} \mathrm{CN}_{2}$ to blueberry in the southeastern United States include increased spring budbreak and vegetative growth, shorter FDPs with earlier harvest periods, increased mean fruit FW, a slight increase in total yield, and improved of bush architecture on some cultivars.

\section{Literature Cited}

Dokoozlian, N.K. and L.E. Williams. 1995. Chilling exposure and hydrogen cyanamide interact in breaking dormancy in grape buds. HortScience 30:1244-1247.

Erez, A. 1987. Chemical control of budbreak. HortScience. 22:1240-1243.

Krewer, G., D.S. NeSmith, and B. Mullinix. 1997. Treatments to accelerate leaf development in blueberries. HortScience 32:595.

Lyrene, P.M. and J.G. Williamson. 1997. Highbush blueberry varieties for Florida. Proc. Fla. State Hort. Soc. 110:171-174.

Maust, B.E., J.G. Williamson, and R.L. Darnell. 1999. Flower bud density affects vegetative and fruit development in field-grown southern highbush blueberry. HortScience 34:607610.

NeSmith, D.S. and D.C. Bridges. 1992. Modeling chilling influence on cumulative flowering: A case study using 'Tifblue' rabbiteye blueberry. J. Amer. Soc. Hort. Sci. 117:698-702.

NeSmith, D.S., G. Krewer, and J.G. Williamson. 1998. A developmental scale for assessing vegetative budbreak in rabbiteye blueberry. HortScience 33:757.

Seiler, C.J., L. Fuchigami, and T.H. Chen. 1991. Budbreak and phytotoxicity in 'Redhaven' peaches induced by hydrogen cyanamide at different dormancy stages. HortScience 26 Abstr. 335.

Shulman, Y., G. Nair, and S. Lavee. 1986. Oxidative processes in bud dormancy and the use of hydrogen cyanamide in breaking bud dormancy. Acta Hort. 179:141-148.

Spiers, J.M. 1978. Effect of stage of bud development on cold injury in rabbiteye blueberry. J. Amer. Soc. Hort. Sci. 103:452-455.

VanSickle, J. 2000 Market Information System. http://www.ifas.ufl.edu/ marketing/ market.html

Williamson, J.G., B.E. Maust, and D.S. NeSmith. 2001. Timing and concentration of hydrogen cyanamide affect blueberry bud development and flower mortality. HortScience 36:922-924. 